\title{
The Field of Cultural Production and the Limits of Freedom in Improvisation
}

\author{
Melvin James Backstrom
}

[A]ny activity or form of expression that pricks through the ideological web of familiarity is [...] already radical in the deepest sense and sustains the only hope possible. For radical does not mean revolutionary; more deeply, it implies the sort of reflection that cracks established patterns of self-evidence. (Goehr 235)

\section{Introduction}

As a way of explaining, and as a way out of, the long running debate between subjective- and objective-based epistemologies, Pierre Bourdieu offers the idea of "regulated improvisation" to describe human behavior (Logic 57). He argues that individuals are not radically free to wholly and continually remake themselves (Sartre 29); but neither are they simply the epiphenomenon of underlying structures (Althusser 119). The first errs in naïvely positing the self as wholly self-constitutive. The second, oppositely, reifies objective structural determinations of subjects and is therefore unable to offer a plausible account of the inexhaustibly various ways in which individuals act and of the seemingly irreducible phenomenological experience of freedom through which they do so. ${ }^{1}$

To escape this seemingly dichotomous choice, Bourdieu proposes the notion of habitus: "the durably installed generative principle of regulated improvisations [...] [that produce] practices which tend to reproduce the regularities immanent in the objective conditions of the production of their generative principle, while adjusting to the demands inscribed as objective potentialities in the situation, as defined by the cognitive and motivating structures making up the habitus" (Outline 78). In other words, there are objective structures that frame understanding and expression; and it is indeed therefore possible to derive generalities and, thereby, create a theory that explains them. But for this theory to be adequate to the full range of subjective potentialities it must recognize the plethora of ways in which practice is realized in terms of these structures. This is because the habitus does not determine the specifics of individual actions, but is, rather, the historically defined social field within which individuals act.

Although Bourdieu's theory has been widely influential in the social sciences, one area in which it has not seen much application is in considerations of the practice of improvisation itself-specifically those of a musical kind. In this paper I will therefore consider how Bourdieu's analysis of "the field of cultural production" ("Field" 37-45) helps explicate certain tendencies within communities of contemporary improvised music. However, I will also reverse this focus to argue that improvised music points to the limitations of Bourdieu's own work on the determinations of artistic practice. For while I would argue that so-called "free improvisation" music has the potential, as many have argued, to enact liberatory alternatives to at least some of the traditional hierarchies that so define music of both a Western high art and pop variety, ${ }^{2}$ this result is by no means a foregone conclusion. The inestimable value of Bourdieu, in this regard, is realized in the profundity of his challenge to uncritical universalizations of the value of artistic practices that do not take into account the integral importance of material and relational distinctions in their constitution, appreciation, and socio-political effects. As important as such considerations are, however, they must be balanced with an appreciation of a degree of inevitable uncertainty that Bourdieu explicitly insists upon, ${ }^{3}$ but did not always live up to in his own work. Though integral to any understanding of the material basis of cultural distinctions, such determinations do not preclude the possibility of artistic practices enabling, or at least participating in, processes of genuine social transformation.

It is therefore from this balancing point between a realization of both the determinate limitations that free improvisation is subject to and its transformative potential that this paper will attempt to work out an ethically grounded (and hopefully aesthetically productive) critique of some of its practices, as well as of the limitations of Bourdieu's own materialist grounding of aesthetic practices. Specifically, I will consider a musician and musical group-Sun Ra and the Grateful Dead-whose performance practices embraced not only the furthest reaches of free improvisation's sonic explorations, but wholly conventional musical styles as well. Although both were defined by genre categories, the diversity of their practices actively subverted the complacent understandings that usually result from such definitions and thereby, to return to this paper's epigraph, "impl[y] the sort of reflection that cracks established patterns of self-evidence." I will argue that it is precisely through the enactment of such a musical diversity that there exists the potential to escape the production of art as a self-interested, capital-accumulating process that Bourdieu so thoroughly analyzes and describes. I would not presume to claim that such practices are always wholly successful in this regard or are the only manner in which this might occur. Rather, I believe that the careers of Sun Ra and the Grateful Dead are compelling evidence for the reality of popular and inclusive, yet artistically and politically progressive, musical practices. 


\section{Towards a critical analysis of "free improvisation"}

[Musical i]mprovisation, by virtue of the interrogative and critical relationships with the practices it (dis)engages, can provide a powerful forum for commentary on the ethics of the "matter" of music, especially since it questions - in its most fully articulated forms-that "matter" with unrelenting curiosity and, in so doing, produces alternatives to the orthodoxies against which it is aligned. (Fischlin and Heble 12-13)

This statement is an exemplary articulation of the promise of musical improvisation to challenge and realize alternatives to conventional musical and social practices. Indeed, it could well be taken as a particularly pithy enunciation of the basis of the relatively new interdisciplinary field of improvisation studies. But from a Bourdieuian perspective, one must question the positing of any necessary, anti-orthodox implications of improvisation, given what is seemingly the inevitable trajectory of all orthodoxy-challenging artistic practices, i.e. the self-conscious avantgarde. Although initially motivated by the desire to challenge artistic and social conventions, avant-garde artists seem to inevitably calcify into a new status quo. As Bourdieu points out:

The history of the field arises from the struggle between the established figures and the young challengers [...] The emergence of a group capable of 'making an epoch' by imposing a new, advanced position is accompanied by a displacement of the structure of temporally hierarchized positions opposed with a given field; each of them moves a step down the temporal hierarchy which is at the same time a social hierarchy; the avant-garde is separated by a generation from the consecrated avant-garde which is itself separated by another generation from the avant-garde that was already consecrated when it made its own entry into the field. ("Field" 60)

Not only is this movement inevitable, but, he argues, it is also fundamentally constitutive of the field of cultural production itself. There is thus little room for Fischlin and Heble's claims of improvisation's essential anti-orthodoxy in Bourdieu's account. Instead, for him, artistic practices that are ostensibly defined by their antagonism to existing norms are but generational position-takings that, over time, inexorably become orthodoxies of their own.

And indeed this does seem to be at least sometimes the case in the "free improvisation" music genre that is understood, in many scholarly accounts, to be the paradigmatic example of improvisation, as well as the best realization of its progressive potential, on account of its ostensible lack of idiomatic traits. Concerning free improvisation, Derek Bailey writes, "[d]iversity is its most consistent characteristic. It has no stylistic or idiomatic commitment. It has no prescribed idiomatic sound. The characteristics of freely improvised music are established only by the sonic-musical identity of the person or persons playing it" (83). And about his early experiences with such music Eddie Prévost recounts that "nothing was allowed that prescribed form. Whenever a compositional device was suggested or whenever there was an intuitive reference to another form of music (for example, jazz), then this allusive quality was annihilated" (357).

As George Lewis has pointed out, however, "it may be difficult to see how free improvisation avoids becoming an idiom like all the others out there"-especially given such a purely negative definition ("Gettin' To Know Y'all” 22). As idioms are, in this account, defined by common stylistic traits, their existence is seemingly inseparable from the development of orthodoxies. And as such a negative definition of a category of music can only make sense within a larger system of genres, it therefore must itself be a genre (Fabbri 131-43).

In this regard, what has often struck me about so-called "free improvisation" is how un-free its performers often are in limiting themselves to only a small portion—-that of the most abstract, rhythmically irregular, and non-tonal-of the total sonic possibilities available for musical instantiation. This structural limitation is not necessarily problematic when enacted in a context in which all present are enabled and empowered to participate in the improvisation and that, therefore, lacks a rigid performer-audience divide. Otherwise, such sonic exclusivity runs the risk of enacting the very social and cultural antagonisms that Bourdieu points out are so omnipresent within the fields of cultural production and, thus, of reproducing, whether consciously or not, the very hierarchies to which free improvisation is ostensibly so antagonistic.

For when such unfamiliar (at least for most people) music is performed, its interpretation in terms of Bourdieu's conflict-defined model is easily made - that is, as the enactment, and thus reproduction, of the performers' (and perhaps also that of non-performing "insider" initiates') relatively high degree of cultural capital over those in the immediate audience, and in society more broadly, who lack the means to make sense of and thereby likely appreciate the music. While the audience for "difficult" art is partly pre-selected to primarily include those able to "get it" on account of their possession of the requisite cultural background, this is rarely entirely the case-especially for genres, such as free improvisation, whose partisans actively seek out less familiar audiences on account of claims to their wider social relevance (Hickey; Thomson). But the existence of such antagonisms obviously complicates the oft- 
stated goal and supposed ability of collective improvisation to dismantle hierarchies and thereby realize a more egalitarian artistic practice. After all, it is difficult to imagine that a practice suffused with social conflict, whether or not it is consciously perceived or intended, could be a method of realizing alternatives to conventional practices that are themselves largely the result of such conflictual processes.

But then why, despite rhetoric that claims an untrammeled freedom to realize a non-idiomatic, 'anything-goes' form of music making, is the reality of free improvisation suffused with its own set of conventions and taboos? For Bourdieu the answer is simple: because free improvisation is in fact not free. Rather, reflecting the unconscious strategies of those agents involved in its production to express, and thereby exalt, their relatively heightened cultural capital, it is defined by its position on the autonomous, i.e. non-commercial, end of the field of cultural production that stands in opposition to music of a heteronomous, i.e. commercial, kind. Bourdieu states, "Thus the opposition between 'genuine' art and 'commercial' art corresponds to the opposition between ordinary entrepreneurs seeking immediate economic profit and cultural entrepreneurs struggling to accumulate specifically cultural capital, albeit at the cost of temporarily renouncing economic profit" ("Field" 82-3). Only by performing "difficult" music that bears as little similarity as possible to that of a commercial kind can those engaged in the cultural enterprise of the musical avant-garde ensure their definition as not commercial, thereby exchanging, at least provisionally, economic return for cultural prestige. Thus, the ostensible freedom of free improvisation is not descriptive but instead ideological-a marketing label that takes advantage of widespread Romantic-based connections between personal freedom and creative authenticity to proclaim its artistic, non-commercial bona fides.

But what of musicians whose practices are not characterized by such stylistic exclusivity? Those who play music of an avant-garde or experimental nature, but also popular styles within the same performance? How might they fit within Bourdieu's field of cultural production? This is a more difficult question to answer because such a mélange would disrupt attempts to define it on the autonomy-heteronomy axis since very different placements would be suggested by different temporal moments. Bourdieu does recognize, however, that "The more the autonomizing process advances, the more possible it becomes to occupy the position of producer without having the properties-or not all of them, or not to the same degree-that had to be possessed to produce the position" ("The Field of Cultural Production" 63). One could therefore understand such groups' practices as reflecting their appearance late in the "autonomizing process," when the position of the avant-garde is already well established. They are free to play not only the "autonomous" music that is the primary expression and reinforcement of their cultural capital, but also that of a "heteronomous" kind in conjunction with the former because they have to only fill the role of avant-garde musicians, not define it through exclusively avant-garde practices as did their predecessors. Such mixed practices could also express the producers' certainty of their own high level of cultural capital as a form of conspicuous cultural consumption. Just as only those who are rich can afford to be profligate, by playing music of a "popular" variety avant-garde musicians might express the certainty of their own position as representatives of autonomous art impervious to its commercial degradations (Veblen 43-62).

These are plausible interpretations that are undoubtedly true in many ways, but it is here that I break from Bourdieu to resist the universality of such structuralist accounts because of their wholly strategic, utilitarian dimension. For within their purview, there is no recognition of an understanding of artistic production as anything other than selfinterested capital (of various kinds) accumulation. Despite a "theory of practice" that is aimed quite specifically at countering objectivist, determinist models of social behaviour, Bourdieu's account of habitus ultimately reinscribes the primacy of determining structures since they are for him what fundamentally explains subjective practices though the mediated workings of the habitus (Jenkins, "Pierre Bourdieu" 273).

One may find little wrong with such a foundational deterministic understanding of cultural practices. However, if one accepts the possibility of their having an ethical-political praxis, then one must also reject a completely determined account of them. As Bernard Crick points out, politics and ethics only exist within a space of personal freedom and "when everything is knowable, determined, or certain, freedom is impossible. Free actions are always, strictly speaking, unnecessary actions" (37). There is, in other words, a necessary and mutually exclusive choice between a wholly deterministic account of cultural production and the positing of its potential ethical-political significance. And if the possibility of the latter is accepted, the obvious next question is how might this possibility be realized given the capital-accumulating, conflict-based strategies that Bourdieu points out are so ubiquitous within the field of cultural production?

There are surely various alternatives, depending of course on the art form in question, but one possibility I would suggest is through a continuously self-critical improvisatory musical practice. This would require an on-going selfinterrogation of the implicit privileging of the performer's cultural position, and a realization-in both senses of the word: to understand and to make real-of the integral role that audience members perform as constitutive of the practice itself. It would thus not content itself with a naïve, monadic conception of improvisational performance based on the Modernist-Romantic ideology of an autonomous individual creator-complicated though this might be by 
collective music making. Instead, it would accept the risk of immersion with the other-performers and audience members alike-in a face-to-face, inter-subjective encounter that aims not at the creation of only the most difficult and challenging of music_-as much that passes for "free improvisation" today seems to_-but rather a radically contextualized musical practice that would intimately reflect its environment. ${ }^{4}$ As Tracey Nicholls argues, in improvisation-based performances,

performers and audience members need to actively engage themselves in the context of the performance (as opposed to passively positioning oneself as an observer or, if performing, as a conduit) in order to fill in any lacunae in the 'plan' that may have been sketched out beforehand [...] What this would be in improvised art-making is a creative process that invites and engages all of the process' participants, musicians and audiences alike. On this view, improvisation is an open invitation to all those present at the performance to contribute themselves to the process and, because of the personal investment that being part of a performative community requires, improvisation becomes a locus in which ethical and political considerations necessarily arise in discussions of aesthetic values and evaluations. (125-6)

Obviously, such a radically contextualized conception of performance practice is very different from that presupposed in through-composed music, and even from some music that is based in improvisation. The realization of the audience as a participant in the music's constitution is especially indicative of the essential difference of such a musical practice by, "demonstrat[ing] a radically open and pluralistic model for living: a commitment to experimentalism and negotiation in social organization, to trying new ideas and structures and seeing how they work, how much sense we can make of them [...] [They] also convey and model ethical commitments to one's fellow community members and to ideals of community" (143). Although a convinced Bourdieuian might yet argue for an interpretation of such a practice as but another form of cultural-capital-based distinction that remains within the field of cultural production's definitional antagonisms, that such radical inclusivity is in its very structuration fundamentally at odds with Bourdieu's conflict-based model suggests either its limitations or perhaps the ultimate incommensurability of a Bourdieuian account of aesthetic practices with those, such as Fischlin and Heble's, that presuppose the possibility of a transcendence of its conflictual dimensions. As John Hall points out,

Bourdieu's account remains deeply infused with ideas from the long tradition of French structuralism [...] [which] is ill prepared to deal with the complexities of multicultural situations tied to complex, market-oriented social formations, except by the holistic device of positing a single matrix or grid of objectively meaningful social location [...] [His] theory of distinction is an effort to subsume other status distinctions within a class framework [...] But there is reason to wonder whether such a move renders analytically inaccessible heterologous and incommensurate processes and interplayings of distinction that obtain on grounds such as ethnicity, gender, religion and life-style. (258-9)

Class is of undoubted importance in understanding how individuals come to make the choices that they do to express both their difference from others (through tendencies towards social elevation and exclusion) as well as their similarities (tendencies towards social solidarity and inclusion). But, as Hall describes, it is hardly the only basis upon which such strategies can be based. Indeed, one could add sexual orientation and even broader categories such as species to his list of pertinent vectors of identity. Perhaps the most expansive of such understandings of solidarity as the basis of individual action is exemplified by the modern environmental movement that is motivated, to a large degree, by a sense of connection with, and recognition of, the intrinsic importance of all life on Earth. The existence of such an expansive notion of being-in-common with that which is, in many ways, radically other points to the possibility of artistic practices constituted not by the narrow parochial exclusivity that Bourdieu's account emphasizes so strongly, but by those of a far more inclusive kind as well.

For though Bourdieu claimed to have escaped structuralism's objective determinism through the "structuring structures and structured structures" of the habitus (Postone, LiPuma, and Calhoun 4), his understanding of the field as space of struggle is itself a structuring structure seemingly without any comparable allowance for being subjectively structured: "His social universe [therefore] ultimately remains one in which things happen to people, rather than a world in which they can intervene in their individual and collective destinies" (Jenkins, Pierre Bourdieu 91). Bourdieu repeatedly points to the necessity of recognizing the importance of individual agency within social scientific theoretical accounts, but in his own practice he errs far more on the side of over-objectivity than vice versa. This is not to deny that cultural production is defined significantly by the field of struggle that Bourdieu so perspicaciously describes; it is instead to argue that just as he was able to bracket his own position within the field in order to develop an analysis of it, so might cultural producers who are aware of its dynamics and desire to create a genuinely inclusive artistic practice-rather than one that reproduces its usual capital/class-based conflicts.

To be clear: I do not intend to suggest that improvising musicians should not challenge their audiences, or that audience members do not themselves have a responsibility to try to understand difficult music. My point is, rather, 
that improvising musicians should not imagine themselves free from the structures, contexts, and histories in which they are implicated. Collective improvisation only makes sense, and can certainly only be successful, in terms of shared understandings of the participants in terms of the practice to be realized, given that it is precisely the conscious interactivity of those involved that is valued most significantly by improvising musical communities. ${ }^{5}$ One can imagine a Cagean-like performance art piece in which varying numbers of musicians "improvise" inside individual soundproof cubicles that they cannot see out of but that observers can see into with the sounds of each simultaneously broadcast to an observing audience. Music of an aleatoric kind would certainly result, but it could hardly be thought to constitute an instance of collective improvisation since there would be no actual interaction among the musicians-only the random concatenation of individually produced sounds. Such a hypothesis points to the importance in improvisational performance of musicians taking into consideration those who make up their audiences. Are those who make it up mostly familiar with, and welcoming of, "difficult" music or not? If the latter, how might the musicians overcome their resistance to unconventional sounds to help them appreciate, even enjoy it?

The claim by some performers to an absolutely autonomous creativity, unburdened by such deliberations, is certainly their right. But such a stance cannot be reconciled with Fischlin and Heble's socially engaged understanding of improvisation that, after all, depends for its efficacy on a critical engagement with, and internal reflection of, its social situatedness. As Susan McClary has written about modernist, avant-garde music in general, "By retreating from the public ear, [it] has in some important sense silenced itself. Only to the tiny, dwindling community that shares modernist definitions of the economy of prestige does the phenomenon make the slightest bit of sense" (66). McClary's "economy of prestige" is much more specifically focused than Bourdieu's "cultural capital" (concerning music of the "avant-garde" rather than cultural production in general), but her argument concerning the general social irrelevance of much "difficult" music is salient in this regard to a consideration of tendencies within freely improvised music as well. Though many free improvisation musicians might claim to belong within the aesthetics of postmodernism rather than that of the high modernism that is the primary object of McClary's critique, this is a distinction without much of a difference given that the practices and sounds that most define their music can be defined within the purview of modernism as easily, and perhaps more so, as that of postmodernism. And despite claims as to the supposed demise of modernism, ${ }^{6}$ its ideals retain a by-no-means insignificant power within the free improvisation community as made evident by the continued valorization of originality and unpredictability. But as Gary Peters points out,

the ideology of innovation turns out to be not quite as disintegrative as it looks, precisely because it never interrupts itself as the dominant logic of becoming any more than it does the new as its immovable têlos. The reassuring linearity of innovation attempts to evade contingency by pressing action into the service of endless novelty, but all this does in the end is rob the unpredictable of any vestige of unpredictability it might have: when everything is unpredictable, unpredictability becomes the most predictable thing imaginable. (105, emphasis added)

The analogy with enjoyably productive verbal conversation is instructive: its success depends on an integration of the familiar-mutually understood words put together in grammatically correct ways-and the unfamiliar-the introduction and use of new (for at least one of the interlocutors) ideas or experiences. Since language necessarily reflects the structures out of which it arises while simultaneously dialectically determining them, so, similarly, any collective improvisation requires a shared understanding of the possibilities of the organization of sound. Without such awareness, the audience, and possibly other performers as well, would be unable to even recognize it qua music, whatever mixture (or lack) of harmony, melody, and rhythm might be improvised. The realization of a degree of dialogicality between performer and audience is thus of crucial importance to an improvisation's success; and since it is performers who are in the de facto position of privilege, they must bear the primary (though not total) responsibility for making the effort to broach this dialogue. There are undoubtedly a plethora of ways in which this kind of performance can be realized, but the musical practices of Sun Ra and the Grateful Dead, as I will show, clearly aimed at doing so. Though by no means always successful, their strategies deserve greater scrutiny than they have hitherto been given, as their success would not only indicate the real possibility of a more ethically engaged improvisational practice, but also demonstrate pathways to its successful realization.

Following from the above quotation from Peters, what is especially interesting about these musicians is their inclusion of an unusually wide range of musical styles within and across individual performances. For although Sun Ra is generally understood as part of the "free jazz" genre he did not limit his music to the sonic textures that typify such a label. And, similarly, though the Grateful Dead is commonly defined as a rock band (psychedelic, jam-band, or otherwise), they consistently performed music that had little sonic resemblance to what is conventionally understood as rock music. Such classifications are not to naïvely posit that musical genres are wholly defined by sonic characteristics; ${ }^{7}$ it is, instead, to consider the freedom of free improvisation as a positive freedom to perform any musical style or form imaginable rather than the negative freedom from traditional styles and forms that often characterizes free improvisation performances. ${ }^{8}$ Consider this description: 
A typical [Grateful] Dead concert [...] assaults the senses with so many different musical forms and styles that the diversity itself can be somewhat disorienting. On any given night, you might hear [...] country classics [...] Motown R\&B [...] seminal rock and roll tunes [...] a fast blues or two; jazzy rhythms and chord progressions; extended solos featuring exotic African and Asian percussions; cacophonous feedback and electronic rumblings that shake every molecule in your body; and more. (Jackson 157)

A particularly interesting example (although one of many) is their performance on May 21, 1974 in Seattle, Washington (Grateful Dead). Beginning in a decidedly country and western vein, the group goes on to use a bewildering array of other styles. For the most part they stay within the confines of tonality and regularly repeating rhythms, as one expects from a rock band, but they also venture into much more experimental forms. Particularly salient is their version of "Playing in a Band" that begins with the same rock song, 10/4 rhythmic form as on its studio recording (Weir, Ace), but the group (around 2:45) then ventures into the furthest reaches of sonic explorations over the majority of its 46 remaining minutes, only returning to the form of the studio recording around the 44:25 mark. It is difficult to imagine making unpredictable music more unpredictable than this. ${ }^{9}$

Bob Weir, the rhythm guitarist in the Grateful Dead, explains how such improvised music-making works: "We do read the crowd, all of us, and work with whatever spirit arises from that particular evening. Every time we do a song, it's different, because the mood of the evening is different. The crowd is only a part of that, but a fairly large part" (Gans 121). And in a response to a question as to how he approaches performances in which the audience is not familiar with the music of Ratdog, his primary group since the Grateful Dead's demise (and whose musical aesthetic is identical), Weir states:

For a regular show, most of our audience is well familiar with what we do and we have a fairly large repertoire and we try to mix things up for them. For a show like Bonnaroo we're going to try to hit them with stuff that's a little more accessible, like stuff they might have heard on the radio or stuff with hooks in it rather than experimental stuff. ${ }^{10}$ We'll do a little of that too, otherwise it's not a gig for us, but we're going to try to bear in mind that a great many of the kids out there don't know that much about what we're up to and so we're going to try to lead them in a little bit [...] the music happens somewhere between what the band does and what the audience captures; the azimuth there if you will. You know it happens between the band and the audience-it's one thing. And if you're going over their heads then it doesn't amount to much. And so we need to draw them in a bit before we can take off on flights of fancy and stuff like that. ("Interview," emphasis added)

Weir is not saying that he does not play experimental music for audiences largely unfamiliar with his music; rather, he suggests that such a context demands a different approach than playing to their usual audience where such music would be, for the most part, expected and welcomed. Reflecting his statement that their music is constituted dialogically in conjunction with the audience, the band, to avoid losing the interest of the audience by beginning their performance with experimental, less-familiar musical forms ("going over their heads"), at first engages them with music of a more conventional variety in order to be able to later lead them into less familiar musical territory.

Sun Ra had similar ideas about performance and the role of audiences in constituting live music: "I always know what's going to happen when I come in, but it also depends on the people there. I change something every time someone else comes in; I change directions. Because the public is a part of the music too" (qtd. in Szwed 146, emphasis added). It should then not be surprising to find a similar process to what Weir describes in terms of performance practice at work in performances of the Ra-led Arkestra, and, indeed, this is demonstrated in a recording of one of their 1990 performances in London (Sun Ra). The first track, "Frisco," has, after an atmospheric synthesizer introduction, an upbeat big band arrangement that is quite traditional, and thus relatively accessible, in its rhythmic and harmonic textures. Up next, however, is "Shadow World," which has no clear metrical pulse or tonality and features multiple horn players using only extended-playing techniques. Then comes "For the Blue People," which begins with Ra soloing on an electric organ outside of any recognizable scale over a chaotic percussion groove, followed similarly by a trumpet solo, which is then joined by ever more instruments until by the end of the track the entire group seems to be soloing freely en masse. After such sonic chaos, the Ellington ballad "Prelude to a Kiss" unexpectedly appears, providing musical contrast through a welcome diminution in sonic intensity.

Thus for both the Grateful Dead and Sun Ra, a recognition of the importance of the audience in the creation of improvisational-based music leads them to balance "experimental," "outside," or "free" forms with more conventional varieties. While partisans of the autonomous avant-garde may see this as "selling out"-betraying their supposed artistic duty to constantly "push the envelope"-Weir's contention, that "if you're going over their heads then it doesn't amount to much," is a lesson that many improvising musicians (and avant-garde artists in general) could learn from. There are undoubtedly other ways musicians could engage in musical improvisation that appropriately combines musical experimentalism with an ethic of responsibility to the audience members who are helping to constitute it, 
dependent as any such practice is on a myriad of contextual factors, but one manner seems to be in the manner described explicitly by Weir and implicitly by Ra in the performance just discussed: the mixture and contrast of radically diverse musical forms and textures in the creation of a fractured and destabilized, yet coherent unity that intimately reflects its contextual point of origin. ${ }^{11}$ One of the most valuable aspects of musical improvisation is that while it is certainly possible to compose music in a montage-like way, composers can normally at best depend on assumptions as to a piece's performance context, whereas talented and engaged improvisers are able to act and react within it during the performance itself and thus structure their music accordingly.

Not only does such a radically contextual and stylistically diverse improvisatory practice have a far better chance of discharging its ethical obligations than one wedded to the ideals of the autonomous avant-garde, but, following Peters, it has a far better chance of achieving its aesthetic goals. Interestingly, Theodor Adorno suggests something similar in one of his late essays:

A succession in time that denies its own progressivity sabotages the obligations of becoming, of process [...] If a musique informelle [his name for the kind of music he advocates] is expected to absorb thematic, motivic composition unto itself, despite its rejection of it, this only means that music should resolve the dilemma of how to reconcile temporal form and musical content. Paradoxically, however, for this to happen recourse must be had to relatively static segments which alone make it possible to generate some dynamism. For an absolute undifferentiated dynamism would of course lapse once more into the static. (297, emphasis added)

That is, if musicians only make use of the most experimental forms and practices (i.e. "undifferentiated dynamism"), never providing a contrast with more musically familiar "static" sections, then the radical, thought-provoking nature of the former is fatally compromised, becoming instead the very mind-numbing background music that it ostensibly opposes. The pervasiveness and unconscious inculcation of traditional musical forms does ensure that some degree of implicit contrast to any experience of music of a non-traditional variety is practically unavoidable. ${ }^{12}$ But this general experiential background is for the most part insufficient to appropriately contextualize musical practices that seek to explore non-traditional forms and sounds. This reality suggests the need for a kind of improvisation that plays with textural, stylistic differences, blending familiar and unfamiliar forms, in order to engage the audience and problematize attempts to easily categorize the music. In doing so, and thereby denying listeners the mental disengagement that results from the usual processes of auto-classification, such a practice has not only a greater chance of avoiding the imposition of cultural hierarchies by engaging with audiences as constitutive of musical experiences, but of also provoking the kind of reflection that "produces alternatives to the orthodoxies against which it is aligned" (Fischlin and Heble 13) by, to return once again to this paper's epigraph, "prick[ing] through the ideological web of familiarity [...] crack[ing] established patterns of self-evidence" (Goehr 235).

\section{Conclusion}

One must be careful in offering prescriptions as to how others should engage in any artistic practice, and I would certainly not presume to have all the answers as to how improvising musicians can engage their audiences in ethically responsible and historically informed ways. My purpose in this paper is to instead point out the dangers of an improvisatory practice that presumes to step outside of the historically mediated structures in which it is implicated. Lacking the self-critical awareness that would enable it to avoid the impositions of the conflict-ridden battles over capital (cultural, social, economic) that Bourdieu so thoroughly describes, it is difficult to see how such a musical practice would not end up re-inscribing the very hierarchies and structures of domination that it ostensibly, pace Fischlin and Heble, seeks to be working against. While I by no means wish to valorize Sun Ra or the Grateful Dead as paragons of improvisational virtue, at their best they made a sustained effort to engage their audiences as partners in their improvisatory practice by availing themselves of an extremely wide range of stylistic possibilities in order to realize a form of musical expression thoroughly constituted by its performance context. In the words of Grateful Dead drummer Bill Kreutzman, "It's the audience that's the key. They're really the eighth band member. There is some power, be it God or whatever, that enters the Grateful Dead on certain nights, and it has to do with us being open and getting together with the audience" (Garbarini).

On account of its radically contextualized situatedness as a collectively constituted experience rather than a preexisting work of art (Dewey 2-7), such a practice has the potential to avoid enacting the battles over cultural capital that Bourdieu points out are so prevalent within the field of cultural production. Such an approach would also thereby more effectively realize the interrogative and critical relationships that Fischlin and Heble point out are such valuable aspects of improvisational practices, while, contra Bourdieu, leaving open the possibility of its emancipatory role that Adorno so notably foregrounded as integral to understandings of art.

Indeed, the reality of the transcendence of social divisions through the practice of musical improvisation can be seen in the decades-long commitment shown to Sun Ra and his ideas, even after his death, by members of his Arkestra 
despite their relatively low pay and Ra's sometimes imperious demands. This remarkable loyalty was (and, in the case of alto saxophonist Marshall Allen, is still [Gershon 114-18]) the case despite their undoubted ability to find more lucrative work elsewhere (Baraka 254). That they stayed with Ra attests to a value they understood in the music they played with him that could not be reduced to mere money or personal popularity. Such transcendance can also be seen in the acceptance by the Grateful Dead (and other, primarily, jam-band groups that they so strongly influenced) of the recording of their concerts by audience members. Such a practice is still considered anathema by many musical groups on account of their desire to keep control of their music, only allowing others to have it for a price. Very early in their career, however, the Grateful Dead-largely on account of their contextually-improvised performance style_-decided against such a restrictive approach: because each of their performances was different, and since the audiences themselves helped to constitute them, the group members felt no desire to control their recorded diffusion. In the words of their bass player, Phil Lesh, "after we've played [the music], we're done with it. [The audience] can have it. Let them do whatever they want with it" (Lesh). This is a far cry from the sense of possession over artistic commodification that so characterizes capitalist economies, expressing a far too-rare realization of music's essential transience, social dependence, and (potential) ability to overcome the class-cultural divisions that Bourdieu so ably describes.

Of course, the artistic methods delineated in this paper are, in their highly montage-like character, by no means radically new; visual artists, in particular, have long made use of them. But Tia DeNora perspicaciously argues for the often unacknowledged value of such practices in helping to bring about novel forms of social engagement. On account of their fractured multiplicity such practices serve to

widen attention's span. They heighten consciousness, that is, the ability to perceive the differences between things, to fathom, if never contain reality. The task of reason is to accommodate, and through formulation as knowledge, arrange (without suppressing) complexity, diversity, heterogeneity—to hold as much 'material' as is possible within compromised consciousness. (10)

This is a worthy goal indeed. So although I do not wish to completely discount the role of those constantly pushing the limits of audience comprehension, at this post-Cage, seemingly postmodern historical moment in which all sounds, and the lack thereof, have already been made available for musical enactment, other practices, besides a perennial pushing of limits, are called for. I would, in closing, therefore urge that greater attention be paid as to how it is that such a range of possibilities can be used in an ethically, socially responsive manner. Rather than concentrating on the extremes so favoured by modernist aesthetics, improvisational studies needs to pay more attention to performance practices like those of Sun Ra and the Grateful Dead-to how they made use of the transitions, syntheses, and boundaries between the known and unknown, the musically familiar and not-so familiar. An improvisatory musical practice denuded of its pretentions to an absolute freedom and constantly self-critical as to its social role and responsibilities has the best chance of realizing such a welcome possibility.

\section{Notes}

1 "I wanted [...] to reintroduce agents that Lévi-Strauss and the structuralists, among them Althusser, tended to abolish, making them into simple epiphenomena of structure. And I mean agents, not subjects. Action is not the mere carrying out of a rule, or obedience to a rule. Social agents, in archaic societies as well as in ours, are not simply automata regulated like clocks, in accordance with laws they do not understand" (Bourdieu, In Other Words 9).

2 See Alterhaug (99-104), Fischlin and Heble (12-13), Kanellopoulos (98-101), and Lewis, "Improvised Music after 1950" (92).

3 "Once the possibility is admitted that the 'mechanical law' of the 'cycle of reciprocity' may not apply, the whole logic of practice is transformed. Even in cases in which the agents' habitus are perfectly harmonized and the interlocking of actions and reactions is totally predictable from outside, uncertainty remains as to the outcome of the interaction as long as the sequence has not been completed: the passage from the highest probability to absolute certainty is a qualitative leap which is not proportionate to the numerical gap. This uncertainty, which finds its objective basis in the probabilist logic of social laws, is sufficient to modify not only the experience of practice [...] but practice itself, in giving an objective foundation to strategies aimed at avoiding the most probable outcome" (Bourdieu, Outline 9).

${ }^{4}$ And perhaps this objective form of improvisation would also reflect the essence of the medium itself. For as the art most defined by temporality, music seems especially apposite to Levinas' contention "that time is not the achievement of an isolated and lone subject, but that it is the very relationship of the subject with the Other" (39). 
5 At least improvisation of the Afrological variety described by Lewis in "Improvised Music After 1950." See in particular his critique of the common presumptions of autonomous creativity in Eurological forms of improvisation, 117-19.

6 Jürgen Habermas, perhaps most notably, would argue strongly against any notion of the "demise of modernism." See his "Modernity—An Incomplete Project" (passim). And though I use "avant-garde" here to refer to the high modernist art that McClary's article focuses on, I do so because this is how both its partisans and McClary refer to it. Following Peter Bürger, however, I have strong doubts as to the genuine applicability of this term to such art on account of its embracing of the formalistic autonomy that was, as Bürger points out, precisely the target of much avant-garde art in the early twentieth century (Theory, 22-27).

${ }^{7}$ Artistic genres are constituted as much in terms of extra-art, social factors as purely intra-art characteristics (Altman 156-64).

${ }^{8}$ See Berlin, "Two Concepts of Liberty," for the source of this distinction and an expanded discussion of the differences between the positive freedom to and the negative freedom from. Peters usefully elaborates on these two forms of freedom and their implications for understandings of improvisation (22-3). And see Sinclair (20-21) for Sun Ra's own iconoclastic view of freedom.

${ }^{9}$ See Boone, "Tonal and Expressive Ambiguity," for a discussion of the wider context of such unpredictability in the Grateful Dead's performance practice (202-4).

${ }^{10}$ Bonnaroo is a large music festival, begun in 2002, that takes place in Tennessee each June. In its early years it featured mostly jam-bands (i.e. musical groups featuring mostly rock instrumentation and songs but in a highly improvised context), but has significantly broadened its musical selection over the years. See http://www.bonnaroo.com/ for more details.

11 The Association for the Advancement of Creative Musicians (AACM) also fit within such a broad stylistic understanding of improvisational freedom. See Lewis, "Gettin' To Know Y'all," in particular his quotations from members of the Art Ensemble of Chicago from a 1969 interview in Paris: "We play blues, rock, Spanish music, gypsy, African, classical music, European contemporary music, voodoo [. . .] anything you want [. . .] because, in the end, it's 'music' that we play: we create sounds, period."

12 The structures of tonality are, perhaps, the most obvious example of the implicit learning of musical relationships. "Despite the complexity of the [tonal] system, sensitivity to musical structure does not require explicit learning. Because musically naïve listeners are constantly exposed in everyday life to the regularities underlying the music of their culture, they acquire implicit knowledge of them" (Bharucha, Bigan, and Tillman 887).

\section{Works Cited}

Adorno, Theodor. "Vers une musique informelle." Quasi Una Fantasia: Essays on Modern Music. Trans. Rodney Livingstone. New York: Verso, 1992. 269-322. Print.

Alterhaug, Bjørn. "Improvisation on a Triple Theme: Creativity, Jazz Improvisation and Communication." Studia Musicologica Norvegica 30 (2004): 97-118. Web. 25 Jun. 2013. $<$ <ttp://skoleledelse.no/lks/09/pdf/12feb b alterhaug2.pdf>.

Althusser, Louis. "Ideology and Ideological State Apparatus (Notes Towards an Investigation)." Lenin and Philosophy and Other Essays. Trans. Ben Brewster. Marxists. Web. 25 Jun. 2013.

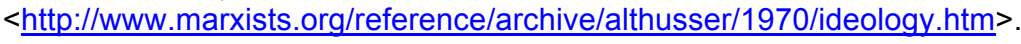

Altman, Rick. Film/Genre. London: British Film Institute, 1999. Print.

Bailey, Derek. Improvisation: Its Nature and Practice in Music. $2^{\text {nd }}$ ed. New York: Da Capo Press, 1993. Print.

Baraka, Amiri. “Jazzmen: Diz \& Sun Ra.” African American Review 29.2 (1995): 249-55. Print. 
Berlin, Isaiah. "Two Concepts of Liberty." In Philosophy: Basic Readings. $2^{\text {nd }}$ ed. Ed. Nigel Warburton. New York: Routledge, 2005. 232-42. Print.

Bharucha, Jamshed J., Emmanuel Bigand, and Barbara Tillman. "Implicit Learning of Tonality: A Self-Organizing Approach.” Psychological Review 107.4 (2000): 885-913. Web. 25 Jun. 2013. $<$ http://a.papavassiliou.free.fr/musico/Documents/Tillmann Bharucha tonality.pdf>.

Boone, Graeme M. "Tonal and Expressive Ambiguity in 'Dark Star." Understanding Rock: Essays in Musical Analysis. Ed. John R. Covach and Graeme M. Boone. New York: Oxford UP, 1997. 171-210. Print.

Bourdieu, Pierre. Outline of a Theory of Practice. Trans. Richard Nice. New York: Cambridge UP, 1977. Print.

---. The Logic of Practice. Trans. Richard Nice. Stanford, CA: Stanford UP, 1990. Print.

---. In Other Words. Trans. Matthew Adamson. Stanford: Stanford UP, 1990. Print.

---. "The Field of Cultural Production, or: The Economic World Reversed." The Field of Cultural Production: Essays on Art and Literature. Ed. Randal Johnson. New York: Colombia UP, 1993. 29-73. Print.

Bürger, Peter. Theory of the Avant-Garde. Trans. Michael Shaw. Minneapolis: Minnesota UP, 1984. Print.

Crick, Bernard. In Defence of Politics. $5^{\text {th }}$ ed. New York: Continuum, 2005. Print.

DeNora, Tia. After Adorno: Rethinking Music Sociology. New York: Cambridge UP, 2003. Print.

Dewey, John. Art as Experience. New York: The Penguin Group, 1934. Print.

Fabbri, Franco. "What Kind of Music?" Popular Music 2 (1982): 131-43. Print.

Fischlin, Daniel and Ajay Heble. "The Other Side of Nowhere: Jazz, Improvisation, and Communities in Dialogue." The Other Side of Nowhere: Jazz, Improvisation, and Communities in Dialogue. Ed. Daniel Fischlin and Ajay Heble. Middletown: Wesleyan UP, 2004. 1-42. Print.

Gans, David. Conversations with the Dead: The Grateful Dead Interview Book. Cambridge, MA: Da Capo Press, 2002. Print.

Garbarini, Vic. "A Tale of Two Drummers." Musician 36 (1981): 68. Web. 25 Jun. 2013. $<$ http://search.proquest.com/docview/962644818/fulltext/13EE5D9C9885E1FCAA2/70?accountid=12339>.

Gershon, Pete. "Twenty First Century Music: Reissues, Memorabilia \& the Ongoing Activities of the Sun Ra Arkestra Under the Direction of Alto Saxophonist Marshall Allen." Sun Ra: Interviews and Essays. Ed. John Sinclair. London: Headpress, 2010. 95-118. Print.

Goehr, Lydia. "Dissonant Works and the Listening Public." The Cambridge Companion to Adorno. Ed. Tom Huhn. New York: Cambridge UP, 2004. 257-85. Print.

Grateful Dead. "Grateful Dead Live at Edmundson Pavilion, U of Washington on 1974-05-21 (May 21, 1974)." Internet Archive. Web. 3 Jun. 2013. <http://archive.org/details/gd74-05-21.sbd.belkin.2597.sbefail.shnf>.

Habermas, Jürgen. "Modernity-An Incomplete Project." Postmodern Culture. Ed. Hal Sinclair. Trans. Seyla BenHabib. London: Pluto Press, 1985. 3-15. Print.

Hall, John. "The Capital(s) of Cultures: A Nonholistic Approach to Status Situations, Class, Gender, and Ethnicity." Cultivating Differences: Symbolic Boundaries and the Making of Inequality. Ed. Michèle Lamont and Marcel Fournier. Chicago: U of Chicago P, 1992. 257-85. Print. 
Hickey, Maud. "Can Improvisation be 'Taught'?: A Call for Free Improvisation in our Schools." International Journal of Music Education 27.4 (2009): 285-99. Web. 25 Jun. 2013. <http://ijm.sagepub.com/content/27/4/285.short>

Jackson, Blair. "Dead Heads: A Strange Tale of Love, Devotion and Surrender." The Grateful Dead Reader. Ed. David G. Dodd and Diana Spaulding. New York: Oxford UP, 2000. 150-64. Print.

Jenkins, Richard. "Pierre Bourdieu and the Reproduction of Determinism." Sociology 16 (1982): 270-81. Print.

---. Pierre Bourdieu, Revised Edition. New York: Routledge, 2002. Print.

Kanellopoulos, Panagiotis A. "Musical Improvisation as Action: An Arendtian Perspective." Action, Criticism, and Theory for Music Education 6.3 (2007): 97-127. Web. 25 Jun. 2013. <http://act.maydaygroup.org/articles/Kanellopoulos6 $3 . \mathrm{pdf}>$.

Lesh, Phil. "Tucker Carlson Interviews Phil Lesh of the Grateful Dead." Web. 25 Jun. 2013. <http://dcspectator.com/blog/?m=20050509>.

Levinas, Emmanuel. Time and the Other. Trans. Richard A. Cohen. Pittsburgh: Duquesne UP, 1987. Print.

Lewis, George. "Improvised Music after 1950: Afrological and Eurological Perspectives." The Other Side of Nowhere: Jazz, Improvisation, and Communities in Dialogue. Ed. Daniel Fischlin and Ajay Heble. Middletown: Wesleyan UP, 2004. 131-62. Print.

---. "Gettin' To Know Y'all: Improvised Music, Interculturalism and the Racial Imagination." Critical Studies in Improvisation 1.1 (2004). Web. 25 Jun. 2013. <http://www.criticalimprov.com/article/viewArticle/6/14>.

McClary, Susan. "Terminal Prestige: The Case of Avant-Garde Composition." Cultural Critique 12 (1989): 57-81. Web. 25 Jun. 2013. <http://www.jstor.org/stable/1354322>.

Nicholls, Tracey. "It Does Too Matter: Aesthetic Value(s), Avant-Garde Art, and Problems of Theory Choice." Diss. McGill University, 2005. Proquest. Web. 25 Jun. 2013. <http://search.proquest.com/pqdtft/docview/304928937/fulltextPDF/13EE5F4A9254E5EC5D3/1?accountid=12 $\underline{339}>$.

Peters, Gary. The Philosophy of Improvisation. Chicago: U of Chicago P, 2009. Print.

Postone, Moishe, Edward LiPuma, and Craig Calhoun. "Introduction: Bourdieu and Social Theory." Bourdieu: Critical Perspectives. Ed. Craig Calhoun, Edward LiPuma, and Moishe Postone. Chicago: U of Chicago P, 1993. 113. Print.

Prévost, Eddie. "The Discourse of a Dysfunctional Drummer: Collaborative Dissonances, Improvisation and Social Theory." The Other Side of Nowhere: Jazz, Improvisation, and Communities in Dialogue. Ed. Daniel Fischlin and Ajay Heble. Middletown: Wesleyan UP, 2004. 353-66. Print.

Sartre, Jean-Paul. Being and Nothingness: A Phenomenological Essay on Ontology. Trans. Hazel E. Barnes. New York: Washington Square Press, 1992. Print.

Sinclair, John. "It Knocks on Everybody's Door: Detroit Sun Interview with Sun Ra; 48 E. $3^{\text {rd }}$ St., New York City, August 1966." Sun Ra: Interviews and Essays. Ed. John Sinclair. London: Headpress, 2010. 19-30. Print.

Sun Ra and his Year 2000 Myth Science Arkestra. Live in London 1990. Mute. 1996. CD.

Szwed, John F. Space Is The Place: The Life and Times of Sun Ra. New York: Pantheon Books, 1997. Print.

Thomson, Scott. "The Pedagogical Imperative of Musical Improvisation." Critical Studies in Improvisation 3.2 (2007). Web. 25 Jun. 2013. <http://www.criticalimprov.com/article/view/353/643>. 
Veblen, Thorstein. The Theory of the Leisure Class. Mineola, New York: Dover Publications, 1994. Print.

Weir, Bob. Ace. Ice Nine Pub. Co. 1988. CD.

---. "Interview with Bob Weir (Part 1)." Transcribed by the author. 2008. Web. 25 Jun. 2013. <https://www.youtube.com/watch?v=YqqiML-Gr28>. 